\title{
ENSO Diversity from an Atmospheric Perspective
}

\author{
Yuko M. Okumura ${ }^{1}$ (D) \\ Published online: 24 June 2019 \\ (C) The Author(s) 2019
}

\begin{abstract}
Purpose of Review The El Niño-Southern Oscillation (ENSO) phenomenon exhibits considerable diversity in the amplitude, pattern, and temporal evolution. The processes causing ENSO diversity are reviewed with focus on the role of atmospheric feedback.

Recent Findings Due to the zonal and meridional asymmetry in tropical Pacific climate, atmospheric response to sea surface temperature (SST) anomalies is highly nonlinear. This leads to diversity in the amplitude and pattern of El Niño, as well as asymmetry in the pattern and duration of El Niño and La Niña. Atmospheric convection changes associated with tropical Pacific decadal variability may modulate ENSO diversity. Furthermore, variability in the Indian and Atlantic Oceans provides additional sources of ENSO diversity through pan-tropical adjustments of atmospheric convection.

Summary The complexity of atmospheric feedback plays an important role in ENSO diversity, but is poorly represented in the Bjerknes feedback. Incorporating convective threshold in defining SST anomalies may help explain various features of ENSO diversity in a unified framework.
\end{abstract}

Keywords ENSO diversity $\cdot$ ENSO asymmetry $\cdot$ ENSO modulation $\cdot$ Pan-tropical climate interactions $\cdot$ SST threshold for convection $\cdot$ Bjerknes feedback

\section{Introduction}

The El Niño-Southern Oscillation (ENSO) phenomenon arises from dynamic and thermodynamic feedbacks between the ocean and atmosphere in the tropical Pacific [1]. Warm (El Niño) and cold (La Niña) phases of ENSO typically last $1-$ 2 years and occur approximately every $3-8$ years. Both El Niño and La Niña usually develop in boreal summer and peak near the end of the calendar year. Sea surface temperature (SST) changes associated with El Niño and La Niña shift the atmospheric deep convection and induce anomalous surface zonal winds, which further enhance SST changes by affecting upwelling and thermocline depth. This so-called Bjerknes feedback is at the heart of the ENSO phenomenon. The intrinsic interannual timescale of ENSO is determined by slow

This article is part of the Topical Collection on Internal Climate Variability

Yuko M. Okumura

yukoo@ig.utexas.edu

1 Institute for Geophysics, Jackson School of Geosciences, The University of Texas at Austin, 10100 Burnet Road,

Austin, TX 78758, USA adjustments of the equatorial ocean to surface wind variations. The atmospheric deep convection changes related to ENSO force a wave train pattern of atmospheric circulation anomalies into the extratropics, affecting weather patterns around the globe. The ENSO thus constitutes an important source of climate variability in the tropics and beyond. It is critical to understand the mechanisms that affect the occurrence, pattern, and duration of individual ENSO events to improve climate predictions.

The decade-long Tropical Ocean-Global Atmosphere (TOGA) program organized by the World Climate Research Program in 1985-1994 accelerated physical understanding of the ENSO phenomenon and teleconnections [2-4]. However, many studies conducted over the ensuing decades highlighted the diversity of individual ENSO events in terms of the pattern and temporal evolution, as well as the asymmetry between $\mathrm{El}$ Niño and La Niña and decadal variability in the ENSO characteristics [5,6]. Furthermore, an increasing number of studies over the past decade have shown that the ENSO is not a phenomenon of the tropical Pacific alone but closely linked to variability in the other two tropical oceans [7]. The diversity and complexity of ENSO pose great challenges in predicting individual ENSO events and their climate impacts and urge the need to understand the mechanisms. These recent research 
progresses also reveal the limitation of conventional ENSO models and indices that are often based on linear oceanatmosphere dynamics and focus on the tropical Pacific. Building upon recent reviews of the ENSO diversity and complexity [5-7], this review paper highlights the importance of atmospheric nonlinearity in causing the diverse behavior of ENSO. The paper also attempts to provide a unified framework to understand the complex nature of ENSO.

\section{Diversity in the Pattern and Amplitude of ENSO Events}

Early studies of the ENSO show that basin-wide SST warming associated with El Niño peaks in the eastern equatorial Pacific [5]. Frequent occurrence of El Niño that deviates from this "canonical" El Niño pattern after the 1990s led researchers to suggest that there exist two distinct modes of ENSO [8-10]. In these non-canonical El Niño events, SST warming is confined to the central equatorial Pacific and peaks near the dateline. The SST warming of this central Pacific (CP) El Niño is primarily driven by changes in zonal advection of heat by ocean currents, whereas changes in vertical advection play an important role in canonical, eastern Pacific (EP) El Niño $[10,11]$. The different roles of ocean currents in generating EP and CP El Niños reflect different climatological oceanic conditions in the eastern and central equatorial Pacific: shallow thermocline in the eastern Pacific and large zonal SST gradient in the central Pacific. Theoretical studies based on a simple model support the existence of both EP and CP ENSO modes $[11,12]$. However, the distinction between EP and CP events is not obvious for La Niña [13], and observed El Niño events cannot be unambiguously categorized into $\mathrm{EP}$ and $\mathrm{CP}$ events. Instead, these modes may be considered as part of a diverse continuum of the ENSO [14-18]. A recent study suggests that the diversity of ENSO pattern represents longitudinal variations of the SST warm pool and the rising branch of the Walker Circulation [18].

There is a strong relation between the amplitude and pattern of ENSO events (Fig. 1). Strong El Niño usually exhibits the EP pattern and moderate to weak El Niño tends to show the CP pattern $[5,9,15,16]$. Moderate to strong La Niña, on the other hand, projects more onto the CP pattern. Thus, EP and CP ENSO modes represent the diversity of ENSO amplitude, as well as the asymmetry in the pattern of El Niño and La Niña. It is shown that the occurrence of strong EP El Niño events is associated with nonlinear response of the atmospheric deep convection to SST anomalies [21], rather than the nonlinearity in oceanic heat advection as suggested earlier [22]. In the eastern equatorial Pacific, where the shallow thermocline maintains the equatorial SST cold tongue, small SST variations have no effect on the atmospheric deep convection. Only sufficiently large SST warming can push absolute SST over the convective threshold and the associated westerly wind anomalies activate the thermocline feedback, leading to the development of a strong EP El Niño event. Stochastic atmospheric forcing, such as westerly wind events (WWEs), helps trigger the development of a strong EP El Niño event, while an initial recharge of the equatorial oceanic heat content is a necessary condition [23-26].

Studies of ENSO diversity focus on variations in the zonal pattern of equatorial SST anomalies, but a few recent studies show that the ENSO also exhibits diversity in the meridional direction over the eastern tropical Pacific [27-29]. The eastern tropical Pacific displays strong equatorial asymmetry in mean climate, with the warmest SST and intertropical convergence zone (ITCZ) displaced north of the equator. At the peak of strong EP El Niño, large positive SST anomalies in the eastern equatorial Pacific can shift the ITCZ to the equator. The associated westerly wind anomalies suppress oceanic upwelling, enhancing SST warming in the eastern equatorial Pacific and off the west coast of South America. This regional oceanatmosphere feedback counteracts the effect of decaying wind anomalies in the central equatorial Pacific and discharge of the equatorial oceanic heat content, delaying the demise of strong EP El Niño until boreal spring-early summer [27, 28]. At the peak of moderate CP El Niño, on the other hand, small positive SST anomalies in the eastern equatorial Pacific can increase precipitation only north of the equator. This equatorially asymmetric atmospheric response develops into a meridional dipole pattern of ocean-atmosphere anomalies in boreal spring, when the tropical Pacific mean climate becomes most symmetric about the equator [28]. The associated crossequatorial southeasterly winds induce oceanic upwelling and dissipate the eastern equatorial Pacific warming. Similar evolution of meridional anomaly pattern, but of opposite sign, is found for La Niña, which projects more onto the CP pattern. The cross-equatorial northwesterly winds that accompany $\mathrm{La}$ Niña sometimes lead to the development of coastal El Niño that occurs independent of basin-wide El Niño [29, 30]. In addition to this eastern Pacific dipole mode, downwelling Kelvin waves excited by WWEs caused an extreme coastal El Niño event in February-April 2017 [29].

\section{Diversity in the Temporal Evolution of ENSO Events}

Studies of the ENSO pattern diversity noted the tendency for strong EP El Niño to transition into La Niña in the second year $[9,10]$. This is in contrast to La Niña, which on average lasts 2 years [31-34]. La Niña persisting into the second year weakens in boreal spring and re-intensifies in summer-fall, resulting in a secondary winter peak in the equatorial SST cooling. The systematic difference in the evolution of El 

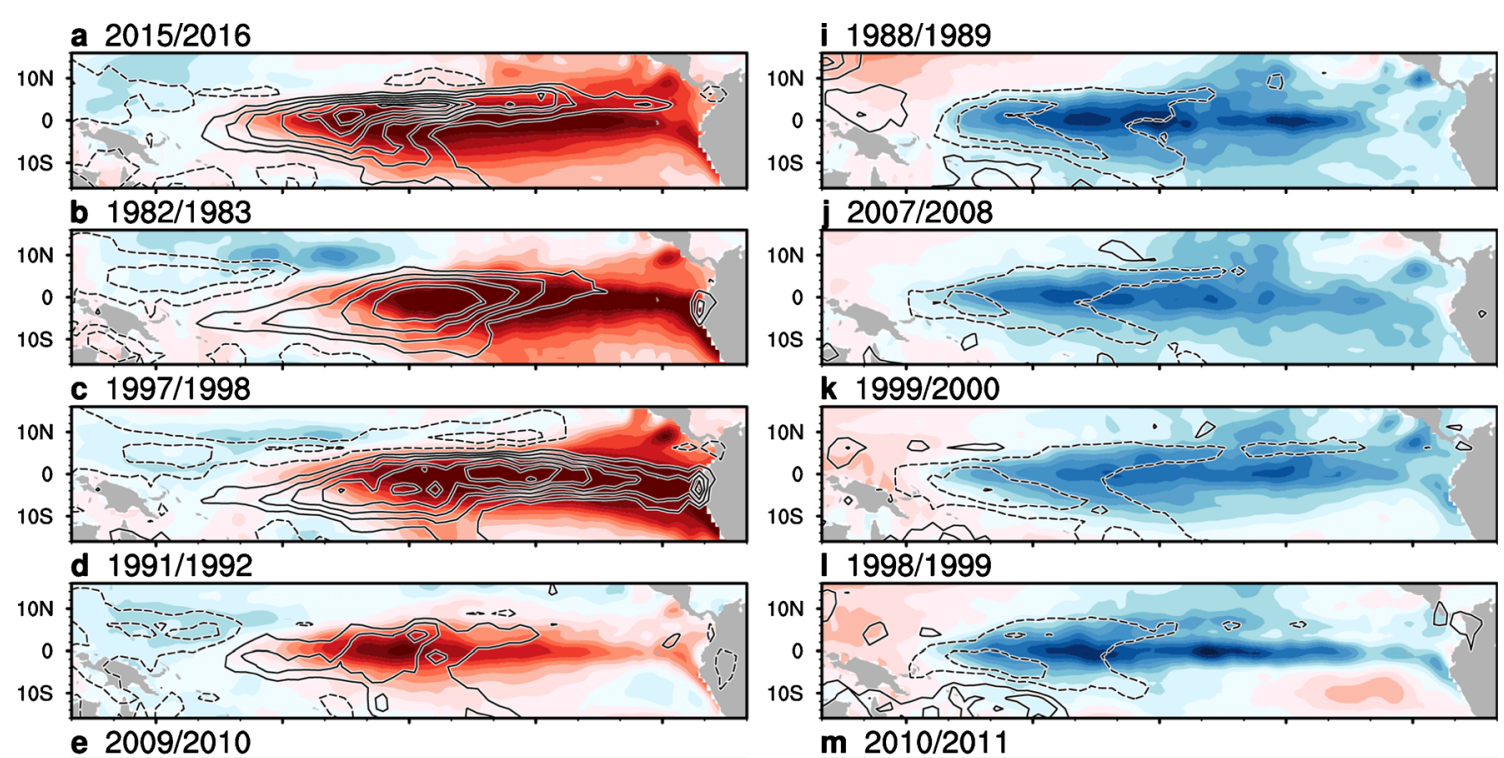

\section{m 2010/2011}
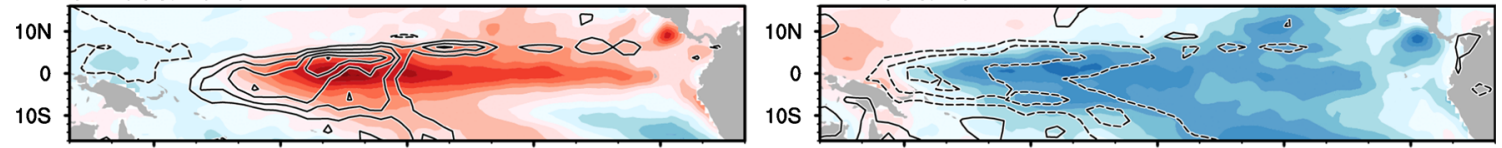

\section{f $2002 / 2003$}
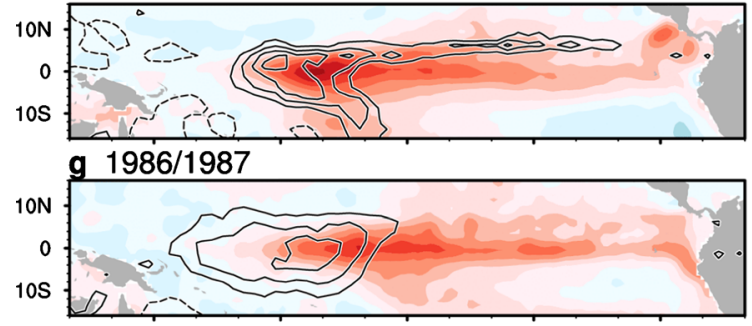

h $1994 / 1995$

\section{n $1984 / 1985$}

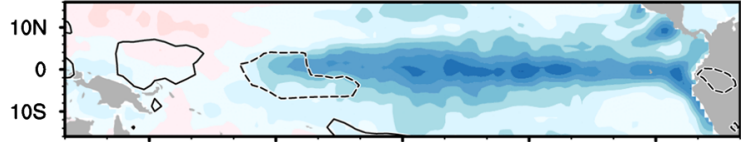

\section{o $1995 / 1996$}

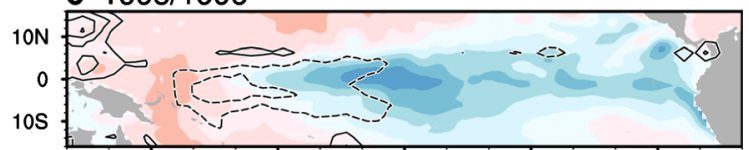

p $1983 / 1984$
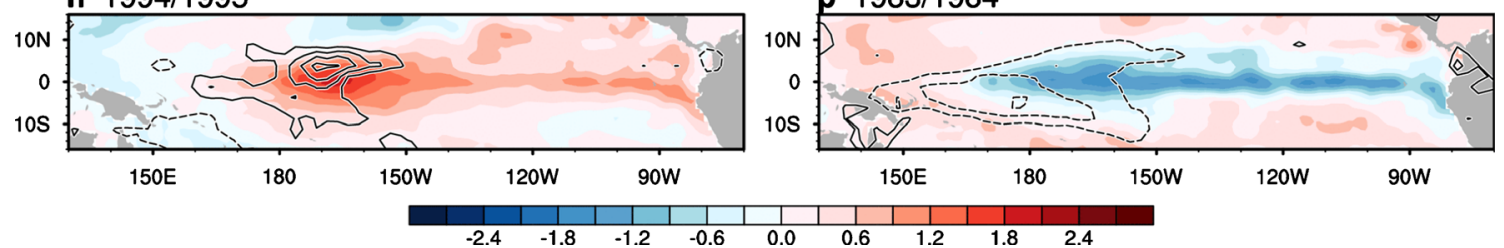

Fig. 1 Variations in the amplitude and pattern of SST and precipitation anomalies during December-February of El Niño and La Niña events based on the NOAA Optimum Interpolation SST (OISST) version 2 and the Global Precipitation Climatology Project (GPCP) version 2.3 datasets for 1982-2018 [19, 20]. a-h Maps of SST $\left({ }^{\circ} \mathrm{C}\right.$; shading) and precipitation (contours at intervals of $2.5 \mathrm{~mm} \mathrm{day}^{-1}$; negative contours dashed and zero contours omitted) anomalies for El Niño events

(2015/16, 1982/83, 1997/98, 1991/1992, 2009/2010, 2002/2003, 1986/1987, and 1994/1995). i-p As in $\mathbf{a}-\mathbf{h}$ but for La Niña events (1988/89, 2007/2008, 1999/2000, 1998/1999, 2010/2011, 1984/1985, $1995 / 1996$, and 1983/1984). The panels are arranged so that the magnitude of SST anomalies averaged in the Niño-3.4 region $\left(5^{\circ} \mathrm{S}-5^{\circ} \mathrm{N}\right.$, $170^{\circ} \mathrm{W}-120^{\circ} \mathrm{W}$; the Niño-3.4 index) decreases from top to bottom. Both SST and precipitation anomalies are linearly detrended

Niño and La Niña cannot be explained by linear oceanatmosphere dynamics nor stochastic atmospheric forcing.

Many studies highlighted the importance of atmospheric nonlinearity for the asymmetric duration of El Niño and La Niña. For example, at the peak of strong El Niño, seasonal southward migration of SST warm pool displaces the precipitation and westerly wind anomalies in the central equatorial Pacific to the south of the equator, hastening the discharge of the equatorial oceanic heat content and hence the event termination $[33,35,36]$. This southward shift of atmospheric anomalies is inconspicuous for La Niña $[33,36]$. It is also suggested that the eastward displacement of precipitation and wind anomalies during strong El Niño compared to La Niña makes surface winds over the western equatorial Pacific more susceptible to delayed negative feedback from the Indian Ocean [37]. Not only the spatial pattern, but also the amplitude of atmospheric anomalies is asymmetric between El Niño and La Niña. Larger precipitation and surface wind anomalies during El Niño compared to La Niña result in stronger delayed negative oceanic feedback [16, 38, 39]. A few recent studies suggest that oceanic nonlinearity may also play an important role. In particular, the delayed thermocline 
feedback is more effective at terminating El Niño than La Niña because the shoaling thermocline can induce large temperature anomalies at the base of the ocean mixed layer [39]. In addition, surface wind anomalies induce larger oceanic wave response in the western equatorial Pacific during El Niño than La Niña because the atmospheric momentum is more efficiently trapped in the relatively shallow upper ocean layer [40]. Besides the ocean-atmosphere dynamical processes, SST damping is stronger during El Niño than La Niña due to larger negative cloud and evaporation feedbacks [41].

While the asymmetry in the duration of El Niño and La Niña is robust for strong events [34], the temporal evolution of moderate to weak El Niño and La Niña varies greatly from event to event [42-44]. It is important to understand the mechanisms controlling the duration of individual ENSO events, as multiyear ENSO events prolong climatic impacts. For example, multi-year La Niña events induce persistent drought conditions over the southern tier of the United States, causing significant socioeconomic impacts $[45,46]$. Observational and model analyses suggest that the duration of La Niña is linked to the amplitude of preceding El Niño (Fig. 2b, d; [44, 48]). Surface wind anomalies associated with strong El Niño cause a large discharge of the equatorial oceanic heat content, which requires more than a year for the tropical Pacific coupled system to return to a neutral state. In addition to the oceanic adjustment, strong El Niño induces significant warming of the tropical Indian and Atlantic Oceans through atmospheric teleconnections, which delays the termination of La Niña by enhancing easterly wind anomalies in the western-central equatorial Pacific [44]. Owing to the oceanic memory and interbasin influences, the occurrence of multi-year La Niña can be predicted up to 2 years in advance [48, 49]. The duration of El Niño, on the other hand, appears to depend on the timing of onset (Fig. 2a, c; [9, 44, 50, 51]). The earlier onset leads to earlier arrival of the negative oceanic feedback and earlier adjustment of the tropical Indian and Atlantic Ocean SSTs, which act to terminate El Niño after the peak [44]. The earlier onset also allows El Niño to grow into a strong EP event [9], resulting in nonlinear atmospheric response that hastens the event termination [33, 35-37]. La Niña events that are not proceeded by strong El Niño and El Niño events that develop late show diverse temporal evolution in the second year (Fig. $2 \mathrm{c}, \mathrm{d} ;$ [44]). In addition to stochastic atmospheric forcing [12, $42,48]$, ocean-atmosphere variability internal to the tropical Indian and Atlantic Oceans may contribute to the diverse evolution of individual ENSO events [44, 49].

\section{Role of Remote Tropical Oceans in ENSO Diversity}

The ENSO exerts significant influence on the tropical Indian and Atlantic Oceans through atmospheric teleconnections [1].
The delayed SST response of these remote tropical oceans, in turn, modulates the atmospheric circulation and provides negative feedback to the ENSO. During the mature-decay phase of El Niño, basin-wide warming of the Indian Ocean forces an atmospheric Kelvin wave and induces easterly winds in the western equatorial Pacific, contributing to the termination of El Niño [52-54]. During La Niña, basin-wide cooling of the Indian Ocean similarly forces westerly winds over the western equatorial Pacific. However, due to the westward displacement of atmospheric anomalies during La Niña compared to El Niño, the negative feedback from the Indian Ocean is ineffective at reversing easterly wind anomalies [37]. In support of this notion, climate model forecasts of the ENSO event evolution are significantly improved by including oceanatmosphere coupling over the Indian Ocean only for El Niño [55]. The Atlantic SST response also acts to terminate the ENSO event by forcing both atmospheric Kelvin and Rossby waves [56, 57]. Experiments with ocean-atmosphere coupled models of various complexities indicate that interactions between the Pacific and the Indian and Atlantic Oceans decrease both the amplitude and period of ENSO [58-61]. The interbasin interactions may account as much as $40 \%$ of the total negative feedback for ENSO [61]. The strong interbasin linkages reviewed here imply that the three tropical oceans should be viewed as a single system linked by means of the atmospheric circulation.

An increasing number of studies show that the Indian and Atlantic Oceans play a more active role in causing ENSO diversity (Fig. 3; [7]). For example, the Indian Ocean dipole (IOD) mode, which is forced by the ENSO but also arises from ocean-atmosphere interactions within the tropical Indian Ocean, affects the strength of El Niño developing during boreal summer-fall $[62,63]$. The IOD may further affect the ENSO event evolution in the following year, providing potential predictability with lead times of more than a year [64]. SST variability internal to the tropical Atlantic has also been shown to affect the development of ENSO events [56, 57, 65-67]. The Atlantic Niño, an equatorial mode analogous to the ENSO but with a peak in boreal summer, contributes to the development of EP ENSO events by affecting the atmospheric deep convection and zonal winds over the westerncentral equatorial Pacific [65-67]. SST variability in the tropical North Atlantic, on the other hand, forces opposite sign of zonal wind anomalies over the eastern and western equatorial Pacific, leading to the development of CP ENSO events [56, 57]. Climate model experiments in which tropical Atlantic SSTs are constrained to observed values suggest that the tropical Atlantic explains up to $25 \%$ of the observed ENSO variability [65-67].

Intriguingly, several studies suggest that the tropical Atlantic-Pacific linkages underwent multidecadal modulations in association with Atlantic multidecadal variability [57, 67-69]. The impact of Atlantic Niño was stronger during 
a El Niño

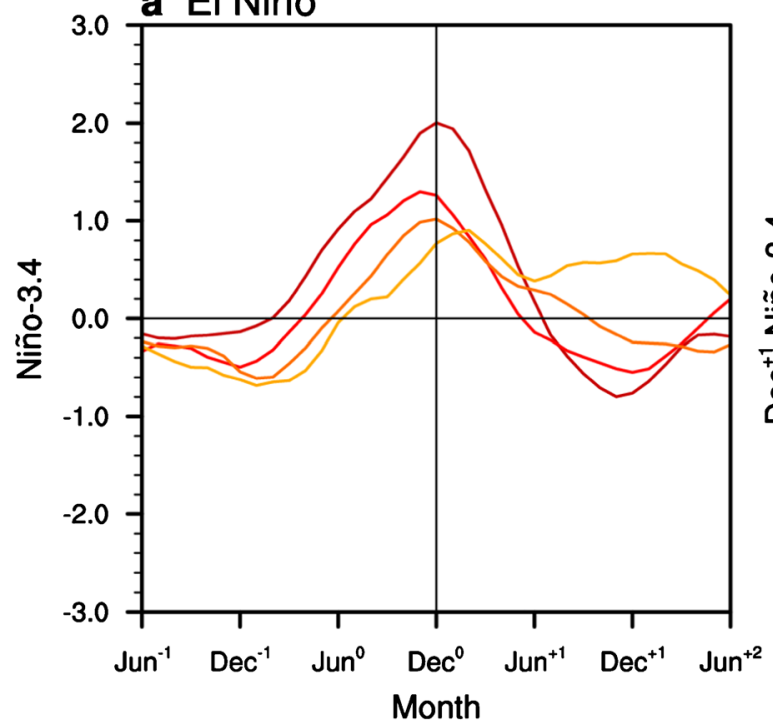

c El Niño

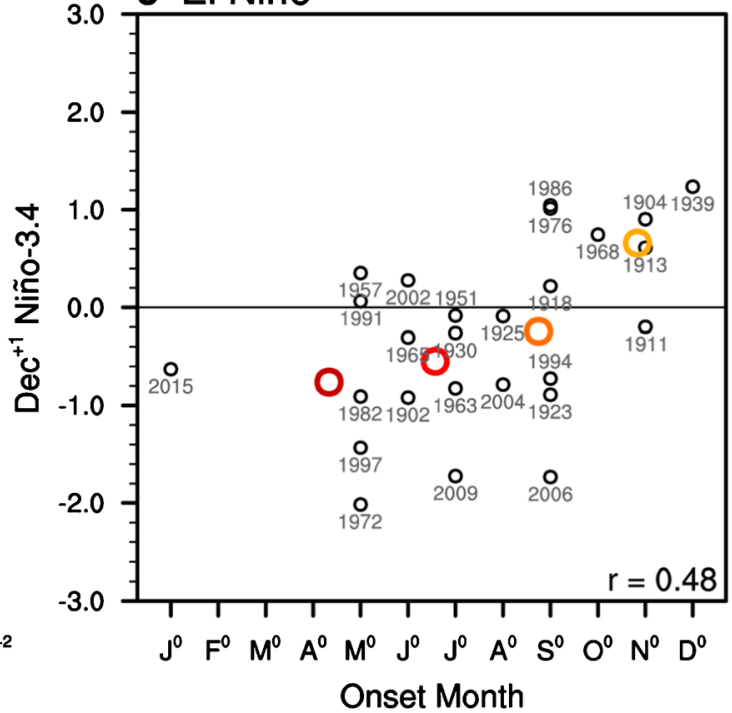

$\operatorname{Jan}^{0}-\mathrm{May}^{0} \operatorname{Jun}^{0}-\mathrm{Jul}^{0} \quad \mathrm{Aug}^{0}-\mathrm{Sep}^{0} \mathrm{Oct}^{0}-\mathrm{Dec}^{0}$

b La Niña

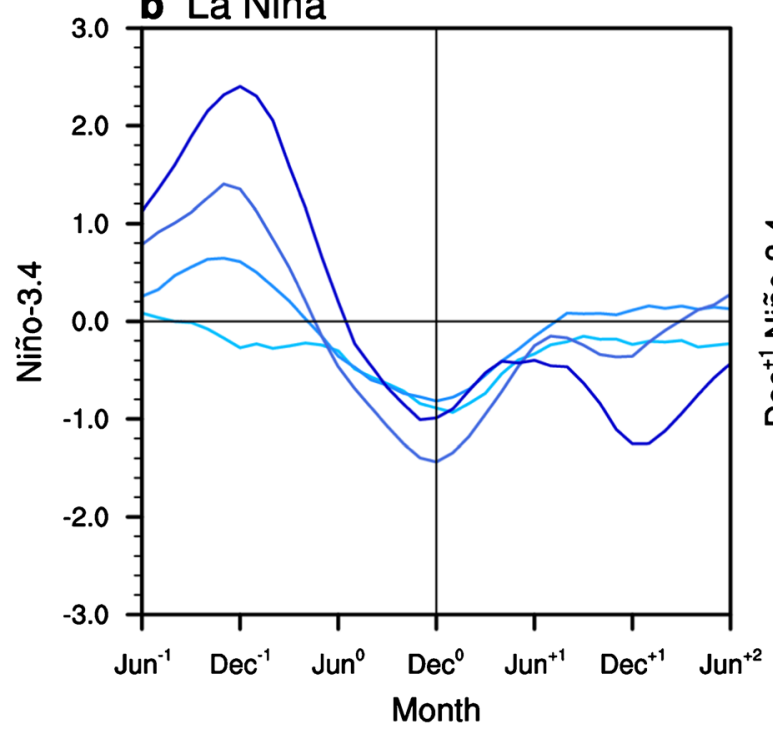

d La Niña

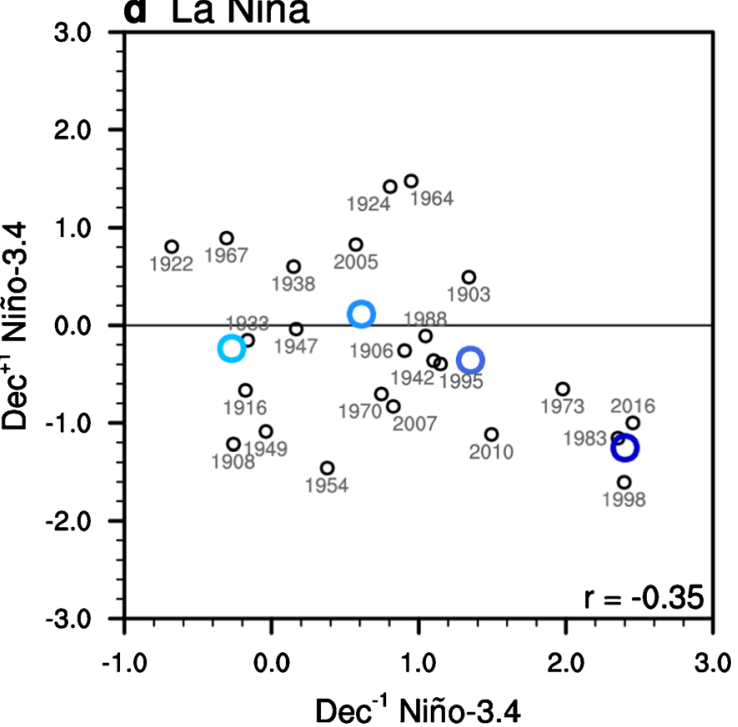

0.0

Fig. 2 Variations in the duration of El Niño and La Niña events and the relation to the onset timing of El Niño and the magnitude of event preceding La Niña based on the Hadley Centre Sea Ice and SST (HadISST) dataset for 1900-2018 [47]. a, b Time series of the Niño-3.4 index $\left({ }^{\circ} \mathrm{C}\right)$ composited for a El Niño events categorized by the onset month and $\mathbf{b}$ La Niña events categorized by the $\operatorname{Dec}^{-1}$ Niño-3.4 index. The colors of composite curves correspond to the categorization criteria shown on color bars. $\mathbf{c}, \mathbf{d}$ Scatterplots of the $\mathrm{Dec}^{+1}$ Niño-3.4 index vs $\mathbf{c}$ the onset month for El Niño events and $\mathbf{d}$ the Dec $^{-1}$ Niño-3.4 index for La Niña events. Small black circles indicate individual events, and large

the negative phase of Atlantic multidecadal variability [67-69], whereas the impact of tropical North Atlantic SST variability intensified with an upswing of Atlantic multidecadal variability in the early 1990s [57]. Such modulations may be explained by changes in both interannual

\section{$1.0 \quad 2.0$}

colored circles represent composite events categorized as in a, b. El Niño and La Niña events are defined when the Niño-3.4 index is greater than 0.75 standard deviations and less than -0.75 standard deviations in any month from $\mathrm{Oct}^{0}$ to $\mathrm{Feb}^{+1}$, respectively. The standard deviation of the Niño-3.4 index is calculated separately for each calendar month. The year when El Niño and La Niña first develop is denoted as year 0 and the months of that year as $\mathrm{Jan}^{0}, \mathrm{Feb}^{0}, \ldots$, and $\mathrm{Dec}^{0}$. The El Niño onset month is defined as the month when the Niño-3.4 index first exceeds $0.5^{\circ} \mathrm{C}$. The Niño-3.4 index is smoothed with a 3-month running mean filter and quadratic trend is removed prior to the analysis

variability and background state of the tropical Atlantic [57, $68,69]$. In particular, changes in the tropical Atlantic background SST may modulate how interannual SST variability induces precipitation anomalies. For example, when the tropical North Atlantic becomes warmer and the Atlantic ITCZ is 


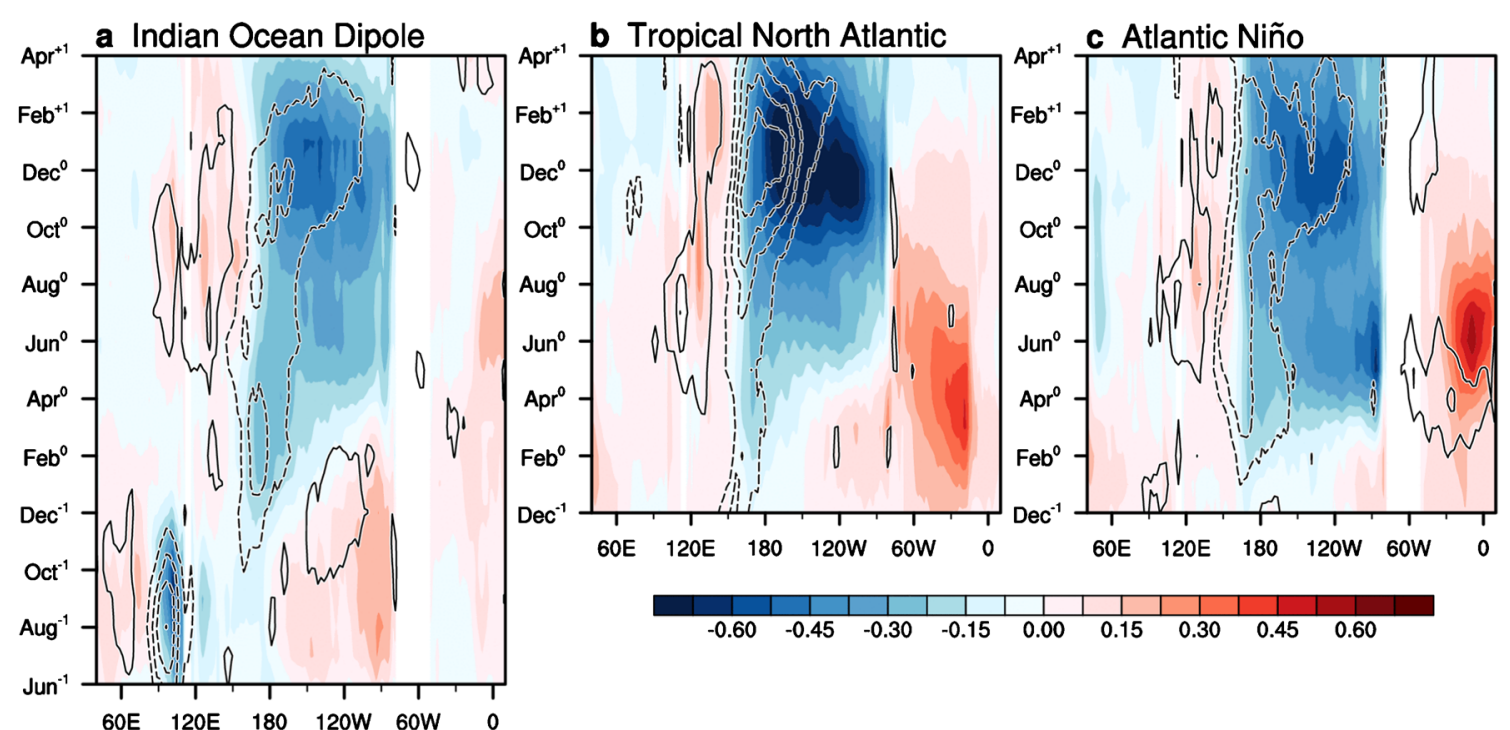

Fig. 3 Impact of Indian and Atlantic Ocean variability on ENSO based on the OISST and GPCP datasets for 1982-2018. a Longitude-time section of SST $\left({ }^{\circ} \mathrm{C}\right.$; shading) and precipitation (contours at intervals of $0.5 \mathrm{~mm} \mathrm{day}^{-1}$; negative contours dashed and zero contours omitted) anomalies along the equator $\left(3^{\circ} \mathrm{S}-3^{\circ} \mathrm{N} ; 10^{\circ} \mathrm{S}-0^{\circ} \mathrm{N}\right.$ between $40^{\circ} \mathrm{E}$ and $\left.110^{\circ} \mathrm{E}\right)$ regressed onto the IOD index for $\mathrm{Sep}^{-1}-\mathrm{Nov}^{-1}$. The IOD index is defined as SST anomalies averaged in $10^{\circ} \mathrm{S}-10^{\circ} \mathrm{N}, 50^{\circ} \mathrm{E}-70^{\circ} \mathrm{E}$ minus those averaged in $10^{\circ} \mathrm{S}-0^{\circ} \mathrm{N}, 90^{\circ} \mathrm{E}-110^{\circ} \mathrm{E}$. b As in a but SST and precipitation anomalies along the equator $\left(3^{\circ} \mathrm{S}-3^{\circ} \mathrm{N} ; 0^{\circ} \mathrm{S}-20^{\circ} \mathrm{N}\right.$ between $80^{\circ} \mathrm{W}$ and $10^{\circ} \mathrm{E}$ ) are regressed onto the tropical North Atlantic SST index $\left(0^{\circ} \mathrm{S}-20^{\circ} \mathrm{N}, 80^{\circ} \mathrm{W}-10^{\circ} \mathrm{E}\right)$ for $\mathrm{Mar}^{0}-\mathrm{May}^{\circ}$. c As in a but SST and

displaced to the north, tropical North Atlantic SST variability is conducive to enhanced precipitation variability compared to when the tropical North Atlantic is cooler and the Atlantic ITCZ is displaced to the south [57]. This idea is supported by recent studies that show a cold SST bias in the tropical North Atlantic weakens the Atlantic-Pacific linkages in climate models [70, 71].

\section{Decadal Variability of ENSO Diversity}

The diversity of ENSO events exhibits distinct decadal variability. Most notably, observational data and paleoclimate proxy records indicate that the amplitude of ENSO varies considerably on decadal-multidecadal time scales [72-74]. During the past century, the ENSO was relatively weak between the 1920s and the early 1960s, rapidly intensified in the late 1960s, and weakened again in the 2000s (Fig. 4a, c). In addition to the amplitude, various other ENSO properties changed around the regime shift of Pacific-wide climate in the late $1970 \mathrm{~s}$, including the periodicity, zonal propagation of equatorial SST anomalies, and El Niño-La Niña asymmetry $[2,32,75,76]$. Furthermore, CP ENSO events became more prevalent than EP events after another Pacific regime shift in the late 1990s [77], leading to the prosperity of ENSO diversity studies [5,6]. Nonetheless, short observational records are precipitation anomalies along the equator $\left(3^{\circ} \mathrm{S}-3^{\circ} \mathrm{N}\right.$ in all longitudes) are regressed onto the Atlantic Niño index $\left(3^{\circ} \mathrm{S}-3^{\circ} \mathrm{N} ; 20^{\circ} \mathrm{W}-0^{\circ} \mathrm{E}\right)$ for $\mathrm{Jun}^{0}-\mathrm{Aug}^{0}$. The impact of ENSO is removed from all the indices by linearly regressing them onto the $\mathrm{Nov}^{-1}-\mathrm{Jan}^{0}$ Niño-3.4 index. All the indices are standardized after removing the ENSO impact. Both SST and precipitation anomalies are smoothed with a 3-month running mean filter and linearly detrended prior to the analysis. The IOD, tropical North Atlantic, and Atlantic Niño indices are negatively correlated with the Nov ${ }^{0}-\mathrm{Jan}^{+1}$ Niño-3.4 index at coefficients of $-0.36,-0.51$, and -0.40 , respectively

insufficient to robustly identify the relationships between ENSO modulations and tropical Pacific decadal variability (TPDV). It should be noted that the leading mode of TPDV, which shows an anomaly pattern similar to the ENSO but with a broader meridional structure, is not correlated with the ENSO amplitude modulation (Fig. 4b, d; [73, 78]).

Long climate model simulations show that the characteristics of ENSO vary closely with the tropical Pacific background state [79-83]. In these models, the ENSO amplitude is negatively correlated with decadal changes in the zonal gradient of background SST and thermocline depth, which manifest as a zonal dipole pattern of anomalies. Recent modeling studies and some observational evidence also show that the relative frequency of El Niño and La Niña events varies with ENSO-like TPDV, with El Niño becoming more frequent than La Niña in a El Niño-like background state [83-86]. Both patterns of background state changes associated with the ENSO modulations emerge as the leading modes of TPDV in climate models $[83,87,88]$. These findings are consistent with analysis of limited observational data (Fig. 4b-e).

The causality of ENSO modulations and TPDV, however, remains controversial. Some studies suggest that the presentday ENSO is a neutrally stable mode and changes in the background state affect the stability and properties of this interannual variability $[11,89,90]$. Indeed, the ENSO is modulated by mean state changes imposed on coupled ocean-atmosphere 


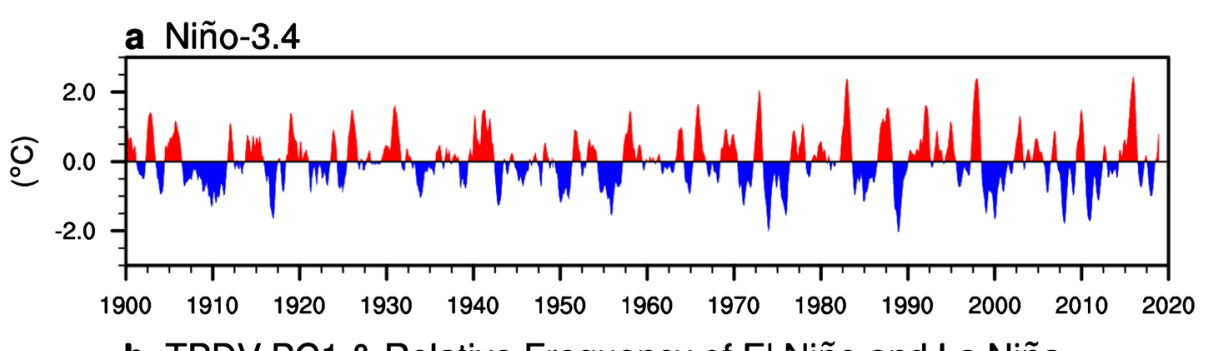

b TPDV PC1 \& Relative Frequency of El Niño and La Niña

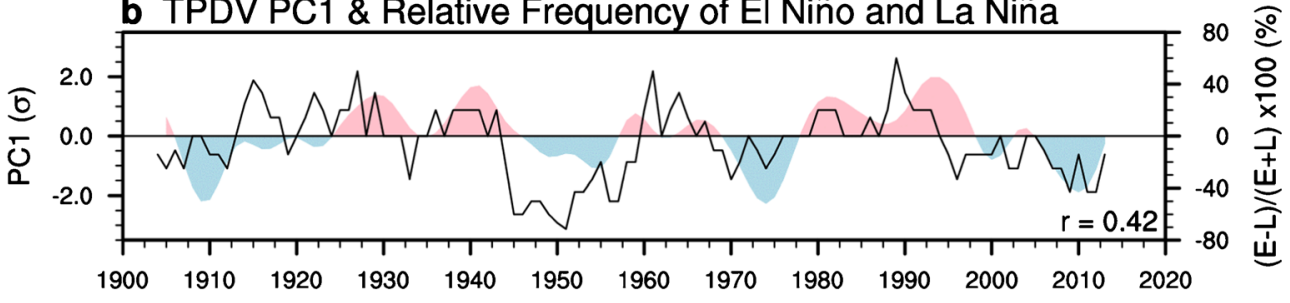

c TPDV PC2 \& ENSO Amplitude
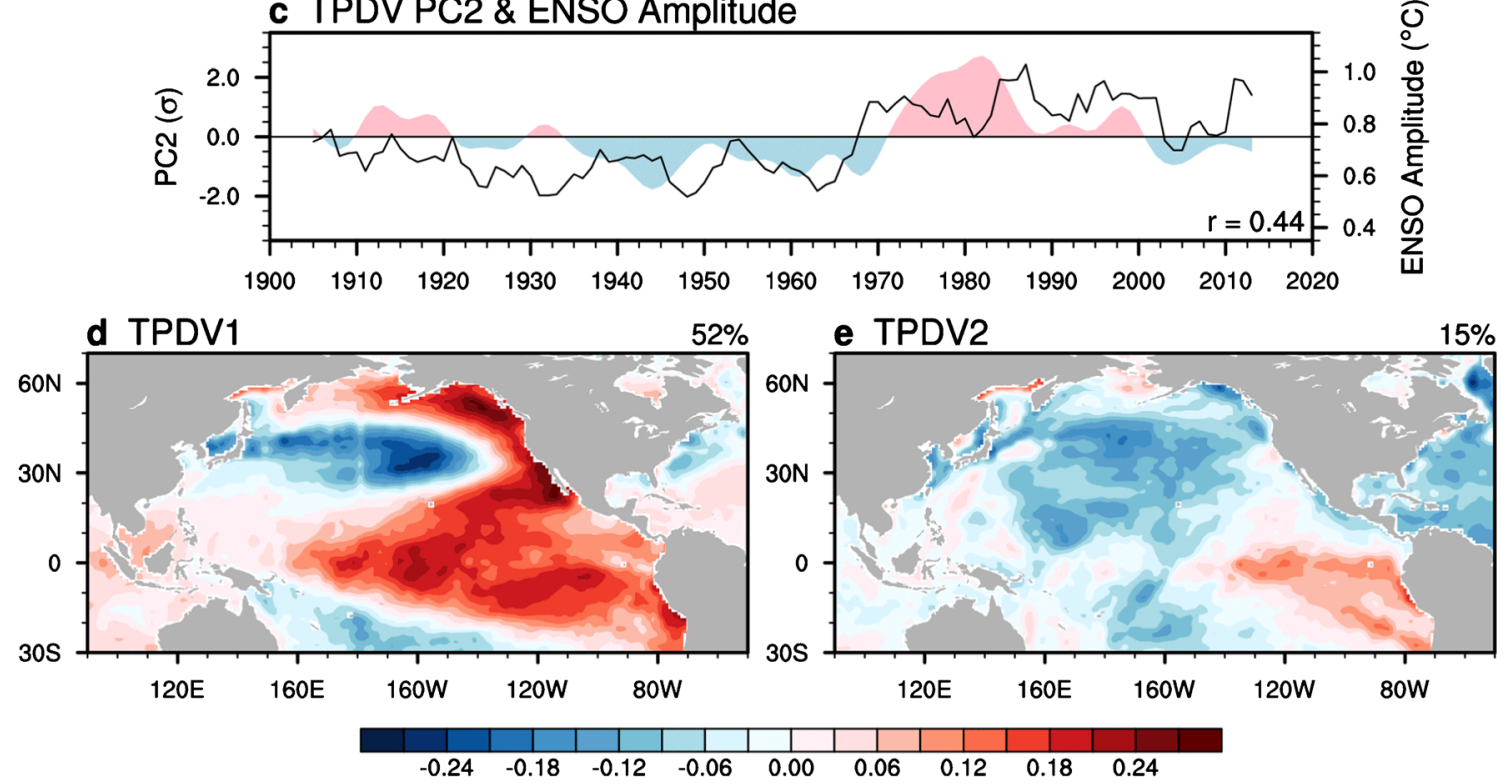

Fig. 4 Decadal modulations of ENSO and the relation to TPDV based on the HadISST dataset for 1900-2018. a Time series of the Niño-3.4 index $\left({ }^{\circ} \mathrm{C}\right)$ smoothed with a 3-month running mean filter. $\mathbf{b}, \mathbf{c}$ Time series of $\mathbf{b}$ the first and $\mathbf{c}$ the second principal components (PC1 and $\mathrm{PC} 2$ ) of 10-year low-pass filtered SST anomalies in the tropical Pacific $\left(23.5^{\circ} \mathrm{S}-23.5^{\circ} \mathrm{N}\right.$, $120^{\circ} \mathrm{E}-80^{\circ} \mathrm{W}$; standard deviation units; shaded curves). Overlaid are time series of $\mathbf{b}$ the relative frequency of El Niño and La Niña events (\%) and $\mathbf{c}$ the ENSO amplitude $\left({ }^{\circ} \mathrm{C}\right)$ in a 10 -year moving window (black curves). The relative frequency of El Niño and La Niña events is defined as $(E-$

$L) /(E+L) \times 100$, where $E$ and $L$ are the numbers of El Niño and La Niña events, respectively. As in Fig. 2, El Niño and La Niña events are defined when the Niño-3.4 index is greater than 0.75 standard deviations and less than -0.75 standard deviations in any month from Oct to Feb, respectively. The ENSO amplitude is defined as standard deviation of the Niño3.4 index. d, e Regression maps of SST anomalies on $\mathbf{d}$ PC1 and e PC2. The two TPDV modes explain 52\% and $15 \%$ of the total filtered variance in the tropical Pacific

models of various complexities [75, 91, 92]. Multiple studies suggest that the ENSO amplitude is affected by the background SST and atmospheric deep convection over the eastern equatorial Pacific [81, 83, 91, 92]. For example, after the late 1990 s, eastern equatorial Pacific cooling and resultant northward displacement of the ITCZ reduced the sensitivity of precipitation response to ENSO SST variability, hindering the development of strong EP El Niño [91, 92]. At the same time, the increased westward gradient of background SST enhanced the zonal advective feedback, favoring the development of CP ENSO events [11, 93, 94]. Interestingly, it is suggested that the tropical Pacific background state change in the late 1990s was partly driven by a shift in Atlantic multidecadal variability through atmospheric teleconnections [91, 95-97].

Other studies conversely argue that decadal modulations of ENSO result merely from low-frequency components of stochastic atmospheric forcing and are unpredictable [98-101]. The randomly generated ENSO changes can, in turn, induce nonzero residuals and affect the background state $[22,79,82$, $102]$. For example, strong ENSO variability acts to increase the mean SST in the east and to decrease the mean SST in the west because of the eastward displacement of El Niño SST 
anomalies compared to La Niña. The ENSO can also generate changes in the background state through oceanic processes without invoking the spatial asymmetry of El Niño and La Niña [82]. The generation of TPDV, however, does not necessarily require the equatorial ocean dynamics. Coupled ocean-atmosphere models in which ocean dynamics is disabled reproduce part of TPDV through oceanic integration of stochastic atmospheric forcing from the extratropics [103-107]. Thus, the strong linkages between ENSO modulations and TPDV found in climate models may be indicative of their two-way interactions $[81,83]$.

\section{Unified Framework for ENSO Diversity: SST Threshold for Atmospheric Convection}

The atmospheric deep convection mediates the coupling between SST and surface wind and affects resultant climate variability in the tropics. The studies reviewed in previous sections highlight the importance of nonlinear relationship between the atmospheric convection and SST in causing the diverse and complex behavior of ENSO. For example, the atmospheric deep convection acts like a switch for the thermocline feedback in the eastern equatorial Pacific and resultant development of strong EP El Niño [21]. The efficiency of this switch may be modulated by decadal changes in the background SST [81, 83, 91].

The traditional use of SST anomalies relative to the climatology provides limited information on the atmospheric deep convection. During both El Niño and La Niña, equatorial Pacific precipitation anomalies are displaced to the west of SST anomalies (Fig. 5f, h). There is little precipitation response to La Niña cooling in the eastern equatorial Pacific as the background SSTs are well below the convective threshold. The instability of tropical atmosphere is largely controlled by distribution of SST as equatorial waves efficiently smooth out the horizontal temperature gradient in the free troposphere. The SST threshold for atmospheric convection closely follows tropical mean SST $\left(T^{*}\right)$, which varies on interannual and longer time scales [108]. The SST threshold increases during El Niño and decreases during La Niña due to the large SST changes in the equatorial Pacific, as well as the delayed SST response of the same sign over the tropical Indian and Atlantic Oceans (Fig. 5a-c). A recent study suggests that SST deviations from the convective threshold at a given time, instead of from the climatology at a given location, may be more useful to understand the diverse behavior of ENSO [18]. Here, we define positive SST deviation from the convective threshold (approximated by $T^{*}$ ) as

$\Delta T=\left(T-T^{*}\right) H\left(T-T^{*}\right)$,

where $H$ is the Heaviside function. Despite being derived only from SST, $\Delta T$ explains the spatial distribution of both climatological and anomalous precipitation over the tropical oceans to surprising detail (Fig. $5 \mathrm{~d}, \mathrm{e}, \mathrm{g}$ ). The patterns of $\Delta T$ and precipitation anomalies are highly correlated for both El Niño and La Niña ( $r=0.75$ and 0.62 , respectively). Thus, $\Delta T$ can be used as a proxy for precipitation. Compared to $\Delta T$, actual precipitation anomalies during El Niño and La Niña are shifted slightly to the west, indicative of the role of moisture advection by the easterly trade winds.

The introduction of $T^{*}$ and $\Delta T$ helps to understand various complex features of the ENSO in a unified framework. For example, strong EP El Niño may develop when initial warming causes SST to exceed $T^{*}$ in the eastern equatorial Pacific. The resultant positive $\Delta T$ (i.e., precipitation) forces anomalous westerly winds into the eastern Pacific and triggers the thermocline feedback, although stochastic atmospheric forcing, as well as influences of remote tropical oceans, could alter the amplitude and pattern of individual events. Cooling of the eastern equatorial Pacific, in contrast, only increases negative disparity from $T^{*}$ in boreal summer, when ENSO events typically develop, and therefore, La Niña cannot evolve into an strong EP event. In general, both SST warming and cooling induce changes in $\Delta T$ over the climatological convective regions, but only SST warming can induce changes in $\Delta T$ over the climatological non-convective regions when the warming overcomes the negative disparity from $T^{*}$. Since SST varies greatly with seasons, the impact of anomalous SST warming and cooling on $\Delta T$ also varies seasonally, leading to distinct seasonal modulations of atmospheric anomalies associated with ENSO [109]. Thus, $\Delta T$ can provide physical explanation for the nonlinear interactions of seasonal cycle and ENSO [110]. It is important to note that local SST changes are not always required to produce changes in $\Delta T$. For example, because $T^{*}$ increases during El Niño, $\Delta T$ decreases over the convective region in the absence of local SST changes. Local SST warming can increase $\Delta T$ only when the magnitude of warming exceeds the magnitude of $T^{*}$ increase. This may explain, for instance, why precipitation decreases over the western equatorial Atlantic but increases over the western Indian Ocean during the mature phase of El Niño, while SST warms over both tropical oceans (Fig. 5e, f).

The same idea can also be used to understand the decadal ENSO modulations and the influences of remote tropical oceans. For example, decadal warming of the eastern Pacific and cooling of the western Pacific help El Niño warming to produce positive $\Delta T$ in the eastern Pacific, promoting the development strong EP El Niño events [81, 83, 91, 92]. Decadal basin-wide warming of the tropical Pacific associated with ENSO-like TPDV, however, increases $T^{*}$ due to concurrent warming of the Indian and Atlantic Oceans, and thus does not necessarily lead to an increase in the ENSO amplitude. Instead, the associated $\Delta T$ increase in the central equatorial Pacific may enhance the chances of El Niño development by inducing anomalous westerly winds over the western 

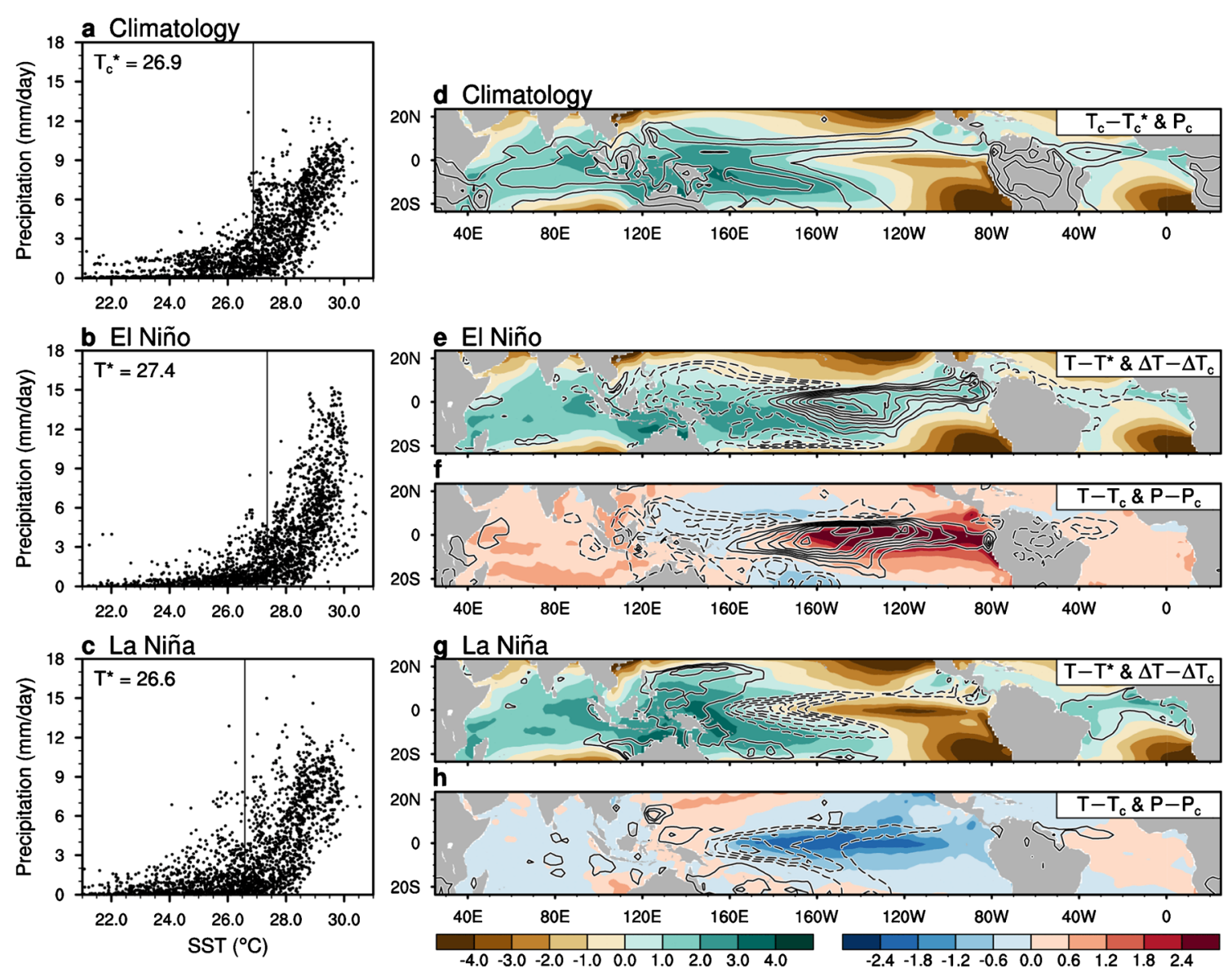

Fig. 5 Nonlinear relationship between SST and precipitation over the tropical oceans $\left(23.5^{\circ} \mathrm{S}-23.5^{\circ} \mathrm{N}\right)$ during December-February of 1982 2018 based on the OISST and GPCP datasets. a-c Scatterplots of SST $\left({ }^{\circ} \mathrm{C}\right)$ vs precipitation $\left(\mathrm{mm} \mathrm{day}^{-1}\right)$ at each grid point for a climatology and composites of strong b El Niño (1982/83, 1997/98, and 2015/16) and $\mathbf{c} \mathrm{La}$ Niña $(1988 / 89,1999 / 2000$, and 2007/08) events. The vertical line indicates tropical mean SST $\left(T^{*}\right)$. d Map of SST deviations from $T^{*}\left({ }^{\circ} \mathrm{C}\right.$; shading) and precipitation (contours at intervals of $3 \mathrm{~mm} \mathrm{day}^{-1}$ ) for

climatology. e Map of SST deviations from $T^{*}\left({ }^{\circ} \mathrm{C}\right.$; shading) and $\Delta T$ anomalies from climatology (contours at intervals of $0.3{ }^{\circ} \mathrm{C}$; negative contours dashed and zero contours omitted) for the composite of strong El Niño events. f Map of SST $\left({ }^{\circ} \mathrm{C}\right.$; shading) and precipitation (contours at intervals of $1.5 \mathrm{~mm} \mathrm{day}^{-1}$; negative contours dashed and zero contours omitted) anomalies from climatology for the composite of strong El Niño events. $\mathbf{g}, \mathbf{h}$ As in $\mathbf{e}, \mathbf{f}$ but for the composite of strong La Niña events. Both SST and precipitation data are linearly detrended prior to the analysis

equatorial Pacific [83]. Furthermore, SST variability in the Indian and Atlantic Oceans can affect $\Delta T$ in the tropical Pacific through changes in $T^{*}$, although subsequent oceanatmosphere interactions within the tropical Pacific are necessary to organize a basin-wide anomaly pattern [53, 56, 64-67]. Thus, the tropical oceans are linked by means of $T^{*}$, which is communicated across the tropical oceans through propagations of atmospheric equatorial waves. Over the remote tropical oceans, decadal changes in the background SST can modulate how interannual SST variability affects $\Delta T$, altering the efficiency of interbasin linkages [57, 70, 71].

\section{Conclusion}

The depiction of ENSO, as an interannual oscillation of tropical Pacific climate caused by the positive Bjerknes feedback and delayed negative oceanic feedback, evolved considerably since the end of the TOGA program, especially over the past decade. The ENSO now represents a wide spectrum of variability in both spatial pattern and temporal evolution, although the basic processes of ocean-atmosphere interactions identified earlier still hold true with varying relative importance. While much focus was given to different types of ENSO patterns, these patterns can be understood as part of the continuum of variability in the zonal extent of western Pacific SST warm pool and associated atmospheric convection. The meridional extent of northeastern tropical Pacific warm pool also causes diversity in the pattern and evolution of ENSO events. Importantly, the studies of ENSO diversity highlighted distinct asymmetry in the pattern of El Niño and La Niña. The asymmetric atmospheric anomalies were shown to lead to asymmetric duration of El Niño and La Niña. Event-to-event variability in the pattern and evolution of ENSO, on the other 
hand, has been attributed not only to stochastic atmospheric forcing unrelated to the ENSO, but also to influences from the remote tropical oceans and decadal changes in oceanatmosphere coupling over all tropical oceans. In particular, the strong interbasin linkages found in recent studies suggest that the ENSO should be viewed as a pan-tropical phenomenon, rather than a tropical Pacific oscillation.

A key factor emerging from the studies of ENSO diversity and complexity is the nonlinear relationship between the atmospheric deep convection and underlying SST. Whether SST anomalies can induce precipitation changes to trigger ocean-atmosphere feedbacks is strongly dependent on the background SSTs, which vary both spatially and temporally. This threshold behavior of atmospheric deep convection may account for the occurrence of strong El Niño events and its decadal variability, as well as the changing influences of remote tropical oceans. The strong linkages of tropical oceans may also be explained by the adjustments of atmospheric convection via changes in the SST threshold that follows the tropical mean SST. The nonlinearity of atmospheric convection response is overlooked in the atmospheric component of the Bjerknes feedback. The traditional use of SST anomalies from the climatology also limits the understanding of atmospheric variability related to the ENSO. Perhaps, we should rethink the way to characterize and analyze the ENSO and other tropical climate variability. For example, the ENSO longitude index, which is defined as the average longitude of tropical Pacific SSTs exceeding the tropical mean value, describes the diversity of ENSO pattern with a single index based solely on SST [18]. SST deviations from the convective threshold can also be used to understand the pattern and evolution of precipitation response to ENSO (Fig. 5). The use of SST threshold is a powerful method as it inherently incorporates the effect of changing SST on seasonal and longer time scales and over the entire tropical oceans, to which the ENSO appears sensitive.

The processes affecting ENSO diversity and complexity reviewed in this paper have important implications for improving the ENSO simulations. Climate models have a longstanding problem of producing excessive SST cold tongue in the eastern equatorial Pacific [111]. The associated westward shift of the upward branch of the Walker circulation has been shown to strongly affect the atmospheric Bjerknes feedback and various characteristics of the ENSO, including the amplitude [112], pattern diversity [113], seasonality, and asymmetry of El Niño and La Niña [114]. Thus, the realistic simulation of climatological SST and atmospheric convection is crucial for the realistic simulation of ENSO [115], which may affect future ENSO projection. Given the widespread climatic impacts of ENSO, how this interannual variability may change in the future is of paramount importance to our society. Although there is no consensus among climate models regarding the future change in the overall ENSO amplitude, models consistently show that El Niño will induce larger precipitation response in the central-eastern Pacific, increasing the occurrence of strong EP El Niño [116, 117]. This is because mean warming enhanced in the equatorial Pacific reduces the barrier for atmospheric convection. A recent study attributes the intermodel variability of ENSO amplitude projection to the diversity of tropical Pacific warming pattern, with the ENSO amplitude increasing in models with reduced zonal SST gradient [118], consistent with the studies of decadal ENSO modulations. Understanding the source of uncertainty in the tropical Pacific warming pattern, including the influences from the Indian and Atlantic Oceans, holds the key to increasing our confidence in future ENSO projection.

Acknowledgements The theme of this review paper was inspired by a stimulating discussion with Dr. Christina M. Patricola. The author also thanks Dr. Shang-Ping Xie and two anonymous reviewers for helpful suggestions.

Funding The author is supported by funding from the US National Oceanic Atmosphere Administration (NA17OAR4310149) and National Science Foundation (OCE1756883).

\section{Compliance with Ethical Standards}

Conflict of Interest The author states that there is no conflict of interest.

Human and Animal Rights and Informed Consent There are no human subjects involved in this research.

Open Access This article is distributed under the terms of the Creative Commons Attribution 4.0 International License (http:// creativecommons.org/licenses/by/4.0/), which permits unrestricted use, distribution, and reproduction in any medium, provided you give appropriate credit to the original author(s) and the source, provide a link to the Creative Commons license, and indicate if changes were made.

\section{References}

1. Deser C, Alexander MA, Xie S-P, Phillips AS. Sea surface temperature variability: patterns and mechanisms. Annu Rev Marine Sci. 2010;2:115-43.

2. Wallace JM, Rasmusson EM, Mitchell TP, Kousky VE, Sarachik ES, von Storch H. On the structure and evolution of ENSO-related climate variability in the tropical Pacific: lessons from TOGA. J Geophys Res. 1998;103:14241-59.

3. McPhaden MJ, Busalacchi AJ, Cheney R, Donguy J-R, Gage KS, Halpern D, et al. The tropical ocean-global atmosphere observing system: a decade of progress. J Geophys Res. 1998;103:14169240.

4. Trenberth KE, Branstator GW, Karoly D, Kumar A, Lau N-C, Ropelewski C. Progress during TOGA in understanding and modeling global teleconnections associated with tropical sea surface temperatures. J Geophys Res. 1998;103:14291-324.

5. Capotondi A, Wittenberg AT, Newman M, Di Lorenzo E, Yu J-Y, Braconnot $\mathrm{P}$, et al. Understanding ENSO diversity. Bull Am Meteorol Soc. 2015;96:921-38. 
6. Timmermann A, An S-I, Kug J-S, Jin F-F, Cai W, Capotondi A, et al. El Niño-southern oscillation complexity. Nature. 2018;559: 535-45.

7. Cai W, Wu L, Lengaigne M, Li T, McGregor S, Kug J-S, et al. Pantropical climate interactions. Science. 2019;363:eaav4236. https://doi.org/10.1126/science.aav4236.

8. Ashok K, Behera SK, Rao SA, Weng H, Yamagata T. El Niño Modoki and its possible teleconnection. J Geophys Res. 2007;112:C11007. https://doi.org/10.1029/2006JC003798.

9. Kao H-Y, Yu J-Y. Contrasting eastern Pacific and Central Pacific types of ENSO. J Clim. 2009;22:615-32.

10. Kug J-S, Jin F-F, An S-I. Two types of El Niño events: cold tongue El Niño and warm pool El Niño. J Clim. 2009;22:1499-515.

11. Xie R, Jin F-F. Two leading ENSO modes and El Niño types in the Zebiak-cane model. J Clim. 2018;31:1943-62.

12. Chen N, Majda AJ. Simple dynamical models capturing the key features of the Central Pacific El Niño. Proc Natl Acad Sci. 2016;113:11732-7.

13. Kug J-S, Ham Y-G. Are there two types of La Niña? Geophys Res Lett. 2011;38:L16704. https://doi.org/10.1029/2010GL044082.

14. Giese BS, Ray S. El Niño variability in simple ocean data assimilation (SODA), 1871-2008. J Geophys Res. 2011;116:C02024. https://doi.org/10.1029/2010JC006695.

15. Takahashi K, Montecinos A, Goubanova K, Dewitte B. ENSO regimes: reinterpreting the canonical and Modoki El Niño. Geophys Res Lett. 2011;38:L10704. https://doi.org/10.1029/ 2011 GL047364.

16. Dommenget D, Bayr T, Frauen C. Analysis of the nonlinearity in the pattern and time evolution of El Niño southern oscillation. Clim Dyn. 2013;40:2825-47.

17. Johnson NC. How many ENSO flavors can we distinguish? J Clim. 2013;26:4816-27.

18. Williams IN, Patricola CM. Diversity of ENSO events unified by convective threshold sea surface temperature: a nonlinear ENSO index. Geophys Res Lett. 2018;45:9236-44.

19. Reynolds RW, Rayner NA, Smith TM, Stokes DC, Wang W. An improved in situ and satellite SST analysis for climate. J Clim. 2002;15:1609-25.

20. Adler RF, Huffman GJ, Chang A, Ferrado R, Xie P-P, Janowiak J, et al. The Version-2 global precipitation climatology project (GPCP) monthly precipitation analysis (1979-present). J Hydrometeorol. 2003;4:1147-67.

21. Takahashi K, Dewitte B. Strong and moderate nonlinear El Niño regimes. Clim Dyn. 2016;46:1627-45.

22. Jin F-F, An S-I, Timmermann A, Zhao J. Strong El Niño events and nonlinear dynamical heating. Geophys Res Lett. 2003;30: 1120. https://doi.org/10.1029/2002GL016356.

23. Fedorov AV, Hu S, Lengaigne M, Guilyardi E. The impact of westerly wind bursts and ocean initial state on the development, and diversity of El Niño events. Clim Dyn. 2014;44:1381-401.

24. Levine AFZ, McPhaden MJ. How the July 2014 easterly wind burst gave the 2015-2016 El Niño a head start. Geophys Res Lett. 2016;43:6503-10.

25. Larson SM. Linking preconditioning to extreme ENSO events and reduced ensemble spread. Clim Dyn. 2017. https://doi.org/10. 1007/s00382-017-3791-x.

26. Puy M, Vialard J, Lengaigne M, Guilyardi E, DiNezio PN, Voldoire A, et al. Influence of westerly wind events stochasticity on El Niño amplitude: the case of 2014 vs. 2015. Clim Dyn. 2017. https://doi.org/10.1007/s00382-017-3938-9.

27. Lengaigne M, Vecchi GA. Contrasting the termination of moderate and extreme El Niño events in coupled general circulation models. Clim Dyn. 2009;35:299-313.

28. Xie S-P, Peng Q, Kamae Y, Zheng X-T, Tokinaga H, Wang D. Eastern Pacific ITCZ dipole and ENSO diversity. J Clim. 2018;31: 4449-62.
29. Peng Q, Xie S-P, Wang D, Zheng X-T, Zhang H. Coupled oceanatmosphere dynamics of the 2017 extreme coastal El Niño. Nat Commun. 2019;10:298. https://doi.org/10.1038/s41467-01808258-8.

30. Takahashi K, Martinez AG. The very strong coastal El Niño in 1925 in the far-eastern Pacific. Clim Dyn. 2017. https://doi.org/10. 1007/s00382-017-3702-1.

31. Larkin NK, Harrison DE. ENSO warm (El Niño) and cold (La Niña) event life cycles: ocean surface anomaly patterns, their symmetries, asymmetries, and implications. J Clim. 2002;15:1118-40.

32. McPhaden MJ, Zhang X. Asymmetry in zonal phase propagation of ENSO Sea surface temperature anomalies. Geophys Res Lett. 2009;36:L13703. https://doi.org/10.1029/2009GL038774.

33. Ohba M, Ueda $\mathrm{H}$. Role of nonlinear atmospheric response to SST on the asymmetric transition process of ENSO. J Clim. 2009;22: 177-92.

34. Okumura YM, Deser C. Asymmetry in the duration of El Niño and La Niña. J Clim. 2010;23:5826-43.

35. Harrison DE, Vecchi GA. On the termination of El Niño. Geophys Res Lett. 1999;26:1593-6.

36. McGregor S, Ramesh N, Spence P, England MH, McPhaden MJ, Santoso A. Meridional movement of wind anomalies during ENSO events and their role in event termination. Geophys Res Lett. 2013;40:749-54.

37. Okumura YM, Ohba M, Deser C, Ueda H. A proposed mechanism for the asymmetric duration of El Niño and La Niña. J Clim. 2011;24:3822-9.

38. Choi KY, Vecchi GA, Wittenberg AT. ENSO transition, duration, and amplitude asymmetries: role of the nonlinear wind stress coupling in a conceptual model. J Clim. 2013;26:9462-76.

39. DiNezio PN, Deser C. Nonlinear controls on the persistence of La Niña. J Clim. 2014;27:7335-55.

40. An S-I, Kim J-W. Role of nonlinear ocean dynamic response to wind on the asymmetrical transition of El Niño and La Niña. Geophys Res Lett. 2017;44:393-400.

41. Chen M, Li T, Shen X, Wu B. Relative roles of dynamic and thermodynamic processes in causing evolution asymmetry between El Niño and La Niña. J Clim. 2016;29:2201-20.

42. Lengaigne M, Boulanger J-P, Menkes C, Spencer H. Influence of the seasonal cycle on the termination of El Niño events in a coupled general circulation model. J Clim. 2006;19:1850-68.

43. DiNezio PN, Deser C, Okumura Y, Karspeck A. Predictability of 2-year La Niña events in a coupled general circulation model. Clim Dyn. 2017;49:4237-61.

44. Wu X, Okumura YM, DiNezio PN. What controls the duration of El Niño and La Niña events? Journal of Climate. 2019. https://doi. org/10.1175/JCLID-18-0681.1.

45. Hoerling M, Kumar A. The perfect ocean for drought. Science. 2003;299:691-4.

46. Okumura YM, DiNezio P, Deser C. Evolving impacts of multiyear La Niña events on atmospheric circulation and U.S. drought. Geophys Res Lett. 2017;44:11614-23.

47. Rayner NA, Parker DE, Horton EB, Folland CK, Alexasnder LV, Rowell DP, et al. Global analyses of sea surface temperature, sea ice, and night marine air temperature since the late nineteenth century. J Geophys Res. 2003;108:4407. https://doi.org/10.1029/ 2002JD002670.

48. DiNezio PN, Deser C, Karspeck A, Yeager S, Okumura Y, Danabasoglu G, et al. A 2 year forecast for a $60-80 \%$ chance of La Niña in 2017-2018. Geophys Res Lett. 2017;44:11624-35.

49. Luo J-J, Liu G, Hendon H, Alves O, Yamagata T. Inter-basin sources for two-year predictability of the multi-year La Niña event in 2010-2012. Sci Rep. 2017;7:2276. https://doi.org/10.1007/ s00382-010-0763-9. 
50. Horii T, Hanawa K. A relationship between timing of El Niño onset and subsequent evolution. Geophys Res Lett. 2004;31: L06304. https://doi.org/10.1029/2003GL019239.

51. Lee S-K, DiNezio PN, Chung E-S, Yeh S-W, Wittenberg AT, Wang C. Spring persistence, transition, and resurgence of El Niño. Geophys Res Lett. 2014;41:8578-85.

52. Annamalai H, Xie S-P, McCreary JP, Murtugudde R. Impact of Indian Ocean Sea surface temperature on developing El Niño. J Clim. 2005;18:302-19.

53. Kug J-S, Kang I-S. Interactive feedback between ENSO and the Indian Ocean. J Clim. 2006;19:1784-801.

54. Ohba M, Ueda H. An impact of SST anomalies in the Indian Ocean in acceleration of the El Niño and La Niña transition. J Meteorol Soc Jpn. 2007;85:335-48.

55. Ohba M, Watanabe M. Role of the indo-Pacific interbasin coupling in predicting asymmetric ENSO transition and duration. $\mathrm{J}$ Clim. 2012;25:3321-35.

56. Ham Y-G, Kug J-S, Park J-Y, Jin F-F. Sea surface temperature in the north tropical Atlantic as a trigger for El Niño/southern oscillation events. Nat Geosci. 2013;6:112-6.

57. Wang L, Yu J-Y, Paek H. Enhanced biennial variability in the Pacific due to Atlantic capacitor effect. Nat Commun. 2017;8:1-7.

58. Kug J-S, Li T, An S-I, Kang I-S, Luo J-J, Masson S, et al. Role of the ENSO-Indian Ocean coupling on ENSO variability in a coupled GCM. Geophys Res Lett. 2006;33:302. https://oi.org/ 10.1029/2001GL014098.

59. Jansen MF, Dommenget D, Keenlyside N. Tropical atmosphereocean interactions in a conceptual framework. J Clim. 2009;22: 550-67.

60. Santoso A, England MH, Cai W. Impact of indo-Pacific feedback interactions on ENSO dynamics diagnosed using ensemble climate simulations. J Clim. 2012;25:7743-63.

61. Dommenget $\mathrm{D}, \mathrm{Yu}$ Y. The effects of remote SST forcings on ENSO dynamics, variability and diversity. Clim Dyn. 2017;49: 2605-24.

62. Saji NH, Yamagata T. Structure of SST and surface wind variability during Indian Ocean dipole mode events: COADS observations. J Clim. 2003;16:2735-51.

63. Annamalai H, Kida S, Hafner J. Potential impact of the tropical Indian Ocean-Indonesian seas on El Niño characteristics. J Clim. 2010;23:3933-52.

64. Izumo T, Vialard J, Lengaigne M, de Boyer Montegut C, Behera SK, Luo J-J, et al. Influence of the state of the Indian Ocean dipole on the following year's El Niño. Nat Geosci. 2010;3:168-72.

65. Rodriguez-Fonseca B, Polo I, Garcia-Serrano J, Losada T, Mohino E, Mechoso CR, et al. Are Atlantic Niños enhancing Pacific ENSO events in recent decades? Geophys Res Lett. 2009;36:2721. https://doi.org/10.1029/2009GL040048.

66. Ding H, Keenlyside NS, Latif M. Impact of the equatorial Atlantic on the El Niño southern oscillation. Clim Dyn. 2012;38:1965-72.

67. Polo I, Martin-Rey M, Rodriguez-Fonseca B, Kucharski F, Mechoso CR. Processes in the Pacific La Niña onset triggered by the Atlantic Niño. Clim Dyn. 2015;44:115-31.

68. Martin-Rey M, Rodriguez-Fonseca B, Polo I, Kucharski F. On the Atlantic-Pacific Niños connection: a multidecadal modulated mode. Clim Dyn. 2014;43:3163-78.

69. Losada T, Rodríguez-Fonseca B. Tropical atmospheric response to decadal changes in the Atlantic equatorial mode. Clim Dyn. 2016;47:1211-24.

70. McGregor S, Stuecker MF, Kajtar JB, England MH, Collins M. Model tropical Atlantic biases underpin diminished Pacific decadal variability. Nat Clim Chang. 2018;8:493-8.

71. Kajtar JB, Santoso A, McGregor S, England MH, Baillie Z. Model under-representation of decadal Pacific trade wind trends and its link to tropical Atlantic bias. Clim Dyn. 2018;50:1471-84.
72. Gu D, Philander S. Secular changes of annual and interannual variability in the tropics during the past century. J Clim. 1995;8: 864-76.

73. McGregor S, Timmermann A, Timm O. A unified proxy for ENSO and PDO variability since 1650. Clim Past. 2010;6:1-17.

74. Li J, Xie S-P, Cook ER, Huang G, D'Arrigo R, Liu F, et al. Interdecadal modulation of El Niño amplitude during the past millennium. Nat Clim Chang. 2011;1:114-8.

75. Wang B, An S-I. A mechanism for decadal changes of ENSO behavior: roles of background wind changes. Clim Dyn. 2002;18:475-86.

76. Santoso A, McGregor S, Jin F-F, Cai W, England MH, An S-I, et al. Late-twentieth-century emergence of the El Niño propagation asymmetry and future projections. Nature. 2013;504:126-30.

77. Lee T, McPhaden MJ. Increasing intensity of El Niño in the Central-Equatorial Pacific. Geophys Res Lett. 2010;37:L14603. https://doi.org/10.1029/2010GL044007.

78. Yeh S-W, Kirtman BP. Pacific decadal variability and decadal ENSO amplitude modulation. Geophys Res Lett. 2005;32: L05703. https://doi.org/10.1029/2004GL021731.

79. Rodgers KB, Friederichs P, Latif M. Tropical Pacific decadal variability and its relation to decadal modulations of ENSO. J Clim. 2004; 17:3761-74.

80. Yeh S-W, Kirtman BP. Tropical Pacific decadal variability and ENSO amplitude modulation in a CGCM. J Geophys Res. 2004;109:C11009. https://doi.org/10.1029/2004JC002442.

81. Choi J, An S-I, Dewitte B, Hsieh WW. Interactive feedback between the tropical Pacific decadal oscillation and ENSO in a coupled general circulation model. J Clim. 2009;22:6597-611.

82. Ogata T, Xie S-P, Wittenberg A, Sun D-Z. Interdecadal amplitude modulation of El Niño-southern oscillation and its impact on tropical Pacific decadal variability. J Clim. 2013;26:7280-97.

83. Okumura YM, Sun T, Wu X. Asymmetric modulation of El Niño and La Niña and the linkage to tropical Pacific decadal variability. J Clim. 2017;30:4705-33.

84. Lin R, Zheng F, Dong X. ENSO frequency asymmetry and the Pacific decadal oscillation in observations and 19 CMIP5 models. Adv Atmos Sci. 2018;35:495-506.

85. Kiem AS, Franks SW, Kuczera G. Multi-decadal variability of flood risk. Geophys Res Lett. 2003;30:1035. https://doi.org/10. 1029/2002GL015992.

86. Verdon DC, Franks SW. Long-term behaviour of ENSO: interactions with the PDO over the past 400 years inferred from paleoclimate records. Geophys Res Lett. 2006;33:L06712. https://doi.org/10.1029/2005GL025052.

87. Yeh S-W, Jhun J-G, Kang I-S, Kirtman BP. The decadal ENSO variability in a hybrid coupled model. J Clim. 2004;17:1225-38.

88. Choi J, An S-I, Yeh S-W, Yu J-Y. ENSO-like and ENSO-induced tropical Pacific decadal variability in CGCMs. J Clim. 2013;26: 1485-501.

89. Jin F-F, Neelin JD. Modes of interannual tropical oceanatmosphere interaction - a unified view. Part I: numerical results. J Atmos Sci. 1993;50:3477-503.

90. Fedorov AV, Philander SG. Is El Niño changing? Science. 2000;288:1997-2002.

91. Kang I-S, No H-H, Kucharski F. ENSO amplitude modulation associated with the mean SST changes in the tropical Central Pacific induced by Atlantic multidecadal oscillation. J Clim. 2014;27:7911-20.

92. Hu S, Fedorov AV. Cross-equatorial winds control El Niño diversity and change. Nat Clim Chang. 2018;8:798-802.

93. Choi J, An S-I, Kug J-S, Yeh S-W. The role of mean state on changes in El Niño's flavor. Clim Dyn. 2011;37:1205-15.

94. Chung P-H, Li T. Interdecadal relationship between the mean state and El Niño type. J Clim. 2013;26:361-79. 
95. McGregor S, Timmermann A, Stuecker MF, England MH, Merrifield M, Jin F-F, et al. Recent Walker circulation strengthening and Pacific cooling amplified by Atlantic warming. Nat Clim Chang. 2014;4:888-92.

96. Li X, Xie S-P, Gille ST, Yoo C. Atlantic-induced pan-tropical climate change over the past three decades. Nat Clim Chang. 2016;6:275-9.

97. Ruprich-Robert Y, Msadek R, Castruccio F, Yeager S, Delworth T, Danabasoglu G. Assessing the climate impacts of the observed Atlantic multidecadal variability using the GFDL CM2. 1 and NCAR CESM1 global coupled models. J Clim. 2017;30:2785810.

98. Flügel M, Chang P. Stochastically induced climate shift of El Niño-southern oscillation. Geophys Res Lett. 1999;26:2473-6.

99. Thompson CJ, Battisti DS. A linear stochastic dynamical model of ENSO. Part II: analysis. J Clim. 2001;14:445-66.

100. Newman M, Shin S-I, Alexander MA. Natural variation in ENSO flavors. Geophys Res Lett. 2011;38:L14705. https://doi.org/10. 1029/2011GL047658.

101. Wittenberg AT, Rosati A, Delworth TL, Vecchi GA, Zeng F. ENSO modulation: is it decadally predictable? J Clim. 2014;27: 2667-81.

102. Vimont DJ. The contribution of the interannual ENSO cycle to the spatial pattern of decadal ENSO-like variability. J Clim. 2005;18: 2080-92.

103. Dommenget D, Latif M. Generation of hyper climate modes. Geophys Res Lett. 2008;35:L02706. https://doi.org/10.1029/ 2007GL031087.

104. Clement A, DiNezio P, Deser C. Rethinking the ocean's role in the southern oscillation. J Clim. 2011;24:4056-72.

105. Okumura YM. Origins of tropical Pacific decadal variability: role of stochastic atmospheric forcing from the South Pacific. J Clim. 2013;26:9791-6.

106. Di Lorenzo E, Liguori G, Schneider N, Furtado JC, Anderson BT, Alexander MA. ENSO and meridional modes: a null hypothesis for Pacific climate variability. Geophys Res Lett. 2015;42:9440-8.
107. Sun T, Okumura YM. Role of stochastic atmospheric forcing from the South and North Pacific in tropical Pacific decadal variability. J Clim. 2019;32:4013-38.

108. Johnson NC, Xie S-P. Changes in the sea surface temperature threshold for tropical convection. Nat Geosci. 2010;3:842-5.

109. Xie S-P, Zhou Z-Q. Seasonal modulations of El Niño-related atmospheric variability: indo-western Pacific Ocean feedback. J Clim. 2017;30:3461-72.

110. Stuecker MF, Timmermann A, Jin F-F, McGregor S, Ren H-L. A combination mode of the annual cycle and the El Niño/southern oscillation. Nat Geosci. 2013;6:540-4.

111. Li G, Xie S-P. Tropical biases in CMIP5 multimodel ensemble: the excessive equatorial Pacific cold tongue and double ITCZ problems. J Clim. 2014;27:1765-80.

112. Kim D, Jang Y-S, Kim D-H, Kim Y-H, Watanabe M, Jin F-F, et al. El Niño-southern oscillation sensitivity to cumulus entrainment in a coupled general circulation model. J Geophys Res. 2011;116: D22112. https://doi.org/10.1029/2011JD016526.

113. Ham Y-G, Kug J-S. How well do current climate models simulate two types of El Niño? Clim Dyn. 2012;39:383-98.

114. Bayr T, Latif M, Dommenget D, Wengel C, Harlaß J, Park W. Mean-state dependence of ENSO atmospheric feedbacks in climate models. Clim Dyn. 2018;50:3171-94.

115. Ham Y-G, Kug J-S. Improvement of ENSO simulation based on Intermodel diversity. J Clim. 2015;28:998-1015.

116. Cai W, Santoso A, Wang G, Yeh S-W, An S-I, Cobb K, et al. ENSO and greenhouse warming. Nat Clim Chang. 2015;5:84959.

117. Cai W, Wang G, Dewitte B, Wu L, Santoso A, Takahashi K, et al. Increased variability of eastern Pacific El Niño under greenhouse warming. Nature. 2018;564:201-6.

118. Zheng X-T, Xie S-P, Lv L-H, Zhou Z-Q. Intermodel uncertainty in ENSO amplitude change tied to Pacific Ocean warming pattern. J Clim. 2016;29:7265-79.

Publisher's Note Springer Nature remains neutral with regard to jurisdictional claims in published maps and institutional affiliations. 